DOI: https://doi.org/10.34883/PI.2021.7.3.012

уДК 616.5

Lukyanau A., Shedzko V., Trizna N.

N.N. Alexandrov National Cancer Center of Belarus, Minsk, Belarus

Лукьянов А.М., Шедько В.В., Тризна Н.М.

Республиканский научно-практический центр онкологии и медицинской радиологии имени

Н.Н. Александрова, Минск, Беларусь

\title{
Pigmented Lesions Assessment in the Rutine Dermatooncologist and Oncologist Practice
}

\author{
Оценка пигмента в рутинной практике дерматоонколога \\ и онкохирурга
}

Abstract

Introduction. The incidence of melanoma tends to rise. Over the past two decades, the absolute annual rates of newly diagnosed cases of melanoma in the Republic of Belarus have increased by 2.5 times. Risk factors for melanoma commonly include fair skin phototypes, male sex, high numbers of melanocytic nevi, dysplastic nevi, immunosuppression, personal or family history of melanoma, and exposure to ultraviolet (UV) radiation.

Melanoma is a unique type of neoplasia - it can be diagnosed through visual examination in the early stages. Traditionally, pigment lesions are examined using the $A B C D+E$ rule. Introduced in 1985 , it has made sizeable progress in the verification of melanoma. However, with the emergence of new methods in the late 1980s and early 1990s (epiluminescence microscopy, dermoscopy) it became evident that the $A B C D+E$ rule is not as effective for early diagnosis of melanoma. As a result, some countries (Australia, New Zealand, Germany, Netherlands, UK) have introduced risk-assessment tools that take into account personal medical history, as well as clinical and dermoscopic analysis of pigment lesions in their national skin cancer screening programs.

Today, the $A B C D+E$ rule is essentially the only tool to verify melanoma used in clinics in the Republic of Belarus. The high relevance of the problem requires a new national screening program for melanoma and non-melanoma skin cancers in the near future.

The aim of the study was to assess the effectiveness of the $A B C D+E$ rule in the early diagnosis of pigmented skin lesions.

Materials and methods. This is a study of a group of patients (854) with pigmented skin lesions (nevi and suspicious of melanoma) based at the outpatient surgery department. The study is direct, diagnostic, observational, retrospective, longitudinal, and single-centered. Statistical processing of the results was carried out using the Statistica 10.0 application package.

Results. There was no significant difference in the sum of the criteria (SC) of the $A B C D+E$ rule in the study groups. Visual clinical evaluation of local status at the initial admission was subjective. Comparing groups with morphologically confirmed melanomas (85) and "melanomas" who later turned out to be non-melanomas (67), the rule showed its inconsistency in half of the cases. Furthermore, SC in the cases with pigmented lesions that initially were assessed as nevi and later turned out to be cutaneous melanoma (17) was 2 times significantly lower. The most specific criteria were A (asymmetry) and B (irregular border) - 96\% and 67\%, respectively. Nevertheless, their sensitivity was assessed as low (for A - extremely low, 8\%). Criteria C (color) and D (diameter) had low indicators of both sensitivity and specificity. The sensitivity of criteria $E$ (evolving) was the 
highest $-62 \%$, but its specificity of $33 \%$ cannot be considered sufficient. No correlation was found between the thickness of the melanoma and the sum of criteria for the $A B C D+E$ rule.

Conclusion. Even the maximum score of the $A B C D+E$ rule cannot be reliable evidence that the doctor is dealing with melanoma, and vice versa, a low score does not guarantee the absence of a malignant neoplasm. Initial dermatooncological examination requires a mandatory assessment of the individual relative risk factors of developing skin melanoma and a dermoscopic examination of the pigment lesions.

Keywords: cutaneous melanoma, $A B C D+E$ rule.

\section{Резюме}

Введение. Повсеместно заболеваемость меланомой имеет тенденцию к росту. За последние две декады абсолютные показатели ежегодной регистрации вновь выявленных случаев меланомы в Республике Беларусь увеличились в 2,5 раза. К факторам риска для меланомы принято относить: светлые фототипы кожи, мужской пол, наличие большого количества меланоцитарных и диспластических невусов, иммуносупрессию, персональную или семейную историю меланомы, а также воздействие ультрафиолетового (УФ) излучения.

Меланома является уникальным видом неоплазий - ее можно обнаружить при визуальном осмотре на ранних стадиях. Классическая оценка пигмента на приеме подразумевает использование правила ABCD+E. Предложенное в 1985 г., оно позволило добиться определенных успехов в верификации меланомы. Однако с появлением новых методик визуализации в конце 1980-х - начале 1990-х гг. (эпилюминисцентная микроскопия, дермоскопия) стало очевидным, что возможности правила $\mathrm{ABCD}+\mathrm{E}$ в ранней диагностике меланомы ограничены. В результате некоторые страны (Австралия, Новая Зеландия, Германия, Нидерланды, Великобритания) в свои национальные программы скрининга рака кожи стали внедрять механизм оценки рисков, учитывающий анамнез, клинику и дермоскопический анализ пигмента.

B Республике Беларусь на современном этапе правило ABCD+E по сути является единственным инструментом верификации меланомы в профильных клиниках. Высокая актуальность проблемы требует разработки в ближайшем будущем стратегии национальной программы скрининга меланомы и немеланомных раков кожи.

Цель. Оценка эффективности использования в клинической практике правила ABCD+E в ранней диагностике пигментных новообразований кожи профильными специалистами.

Материалы и методы. Исследование выполнено в группе пациентов (854) с пигментными новообразованиями кожи (невоидные и подозрительные на меланому) на базе амбулаторного отделения малоинвазивной хирургии в формате прямого, диагностического, обсервационного, ретроспективного, продольного, одноцентрового. Статистическая обработка результатов проведена с использованием пакета прикладных программ Statistica 10.0.

Результаты и обсуждение. Достоверной разницы суммарного показателя правила $A B C D+E$ в исследуемых группах не было получено. Визуальная клиническая оценка локального статуса на первичном приеме имела субъективный характер. На сравнительном примере групп с морфологически подтвержденным диагнозом меланомы (85) и «меланом», которые оказались впоследствии немеланомами (67), правило демонстрировало свою несостоятельность в половине случаев. Более того, у пациентов, пигмент которых изначально оценили как невоидный, а впоследствии оказалось, что это кожная меланома (17), ни в одном из случаев не было заподозрено заболевания по суммарной оценке критерия - он у них был в 2 раза достоверно более низким. Наиболее специфичными явились критерии А (асимметрия) и В (неровность краев) - $96 \%$ и $67 \%$ соответственно. Их чувствительность оценивалась как низкая (для А - экстремально низкая, 8\%). Признаки C (цвет) и D (диаметр) характеризовались невысокими показателями как чувствительности, так и специфичности. Чувствительность Е (эволюция элемента) была самой высокой - $62 \%$, но его специфичность в $33 \%$ не может рассматриваться как 
достаточная. Корреляционной зависимости между толщиной меланомы и суммой критериев правила $\mathrm{ABCD}+\mathrm{E}$ не получено.

Заключение. Даже максимальное количество баллов правила $A B C D+E$ не может быть надежным свидетельством того, что врач имеет дело с меланомой, и, наоборот, низкий показатель суммы может соответствовать злокачественному новообразованию. Первичный дерматоонкологический прием требует обязательной оценки индивидуальных относительных рисков развития меланомы кожи и проведения дермоскопического исследования пигмента.

Ключевые слова: кожная меланома, правило $\mathrm{ABCD}+\mathrm{E}$.

\section{- INTRODUCTION}

The annual incidence of malignant melanoma in European countries ranges from 3-5 per 100,000 (northern and central parts) to $12-35$ per 100,000 (Mediterranean countries), while in Australia and New Zealand this figure reaches 50 or more. The incidence of melanoma has shown a generally upward trend over the past four decades, with a relative stabilization of mortality, except for older men. [3]. Melanoma can develop at any age, with a peak incidence at age 65 [4]. The mortality/morbidity ratio in Eastern European countries is higher than in Western European countries, which indicates the need to improve prevention and early diagnosis in Eastern Europe [5].

Fig. 1-4 show the data of the Belarusian Cancer Register for the last 20 years. The absolute numbers of newly diagnosed cases of melanoma (whole population, men and women) have increased by more than 2.5 times during this period (Fig. 1). The peaks of registration of melanoma (rate per 100,000 ) are in the elderly age group (the higher the age, the higher the risks of developing melanoma); the highest rates are for people in the 8th and 9th decades of life (Fig. 2). Standardized indicators of the incidence

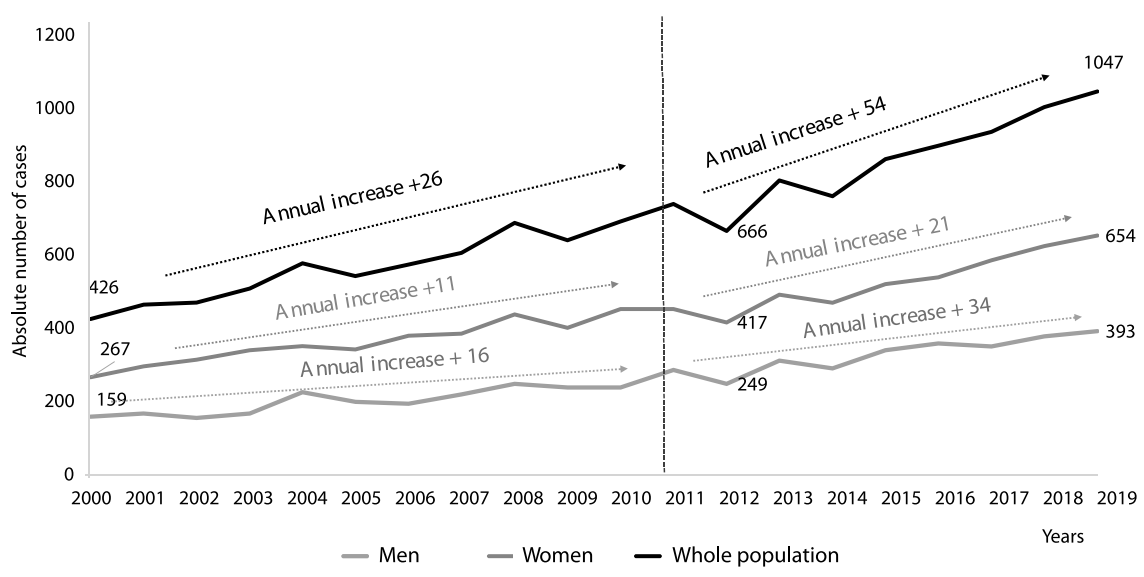

Fig. 1. Melanoma (2009-2019): the absolute numbers of newly diagnosed cases [8] 


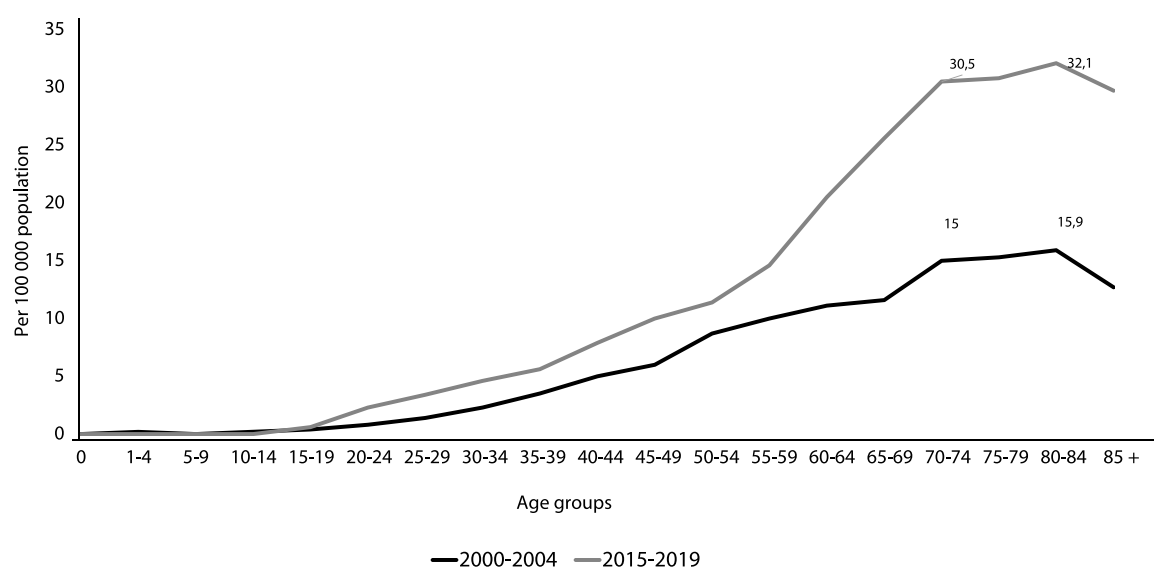

Fig. 2. Melanoma (2009-2019): age-specific incidence rates [8]

of melanoma in Belarus (Fig. 3) tend to increase both among urban and country populations, with a higher gender growth rate in men (1.9/1.7=M/F), with a lower detection rate (5.7/6.8=M/F per 100,000 in $2015-2019)$. On the positive side, there is an increased incidence of melanoma detected in the early stages. For example, over the past 20 years the percentage of registration at stage I has increased by $14.6 \%$ (Fig. 4).

It is generally accepted that ultraviolet (UV) radiation is the leading carcinogen involved in the genesis of melanoma. The nature of UV and exposure time directly affect tumor development. Melanomas that develop on covered skin areas of the body (trunk and limbs usually have intermittent insolation regimes in continental climate zones) are more often associated

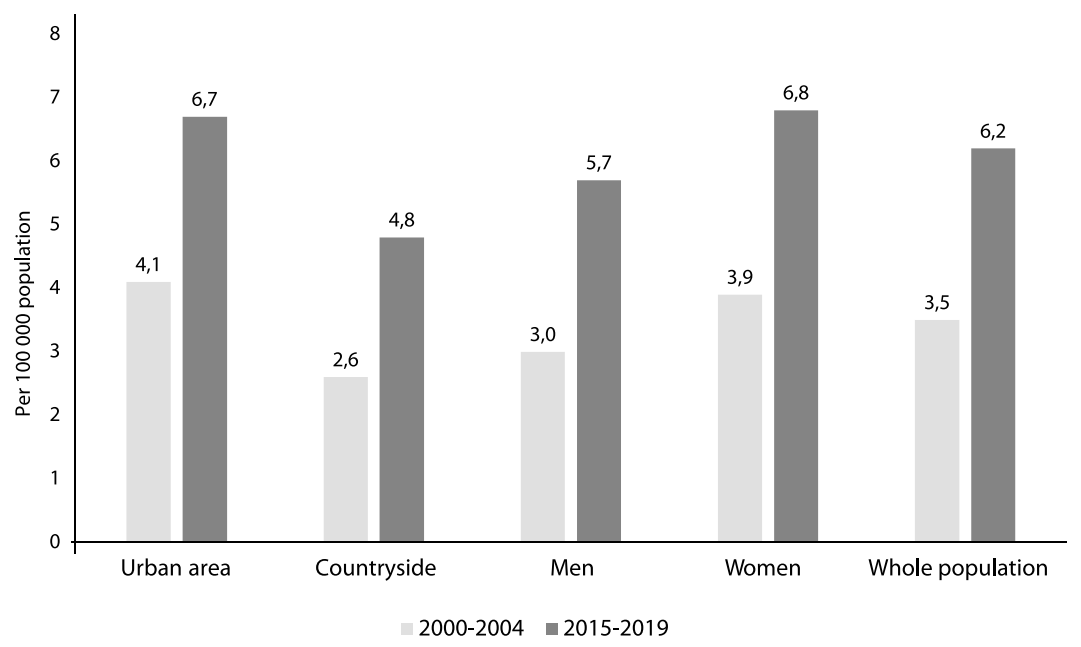

Fig. 3. Melanoma (2009-2019): standardized incidence rates [8] 


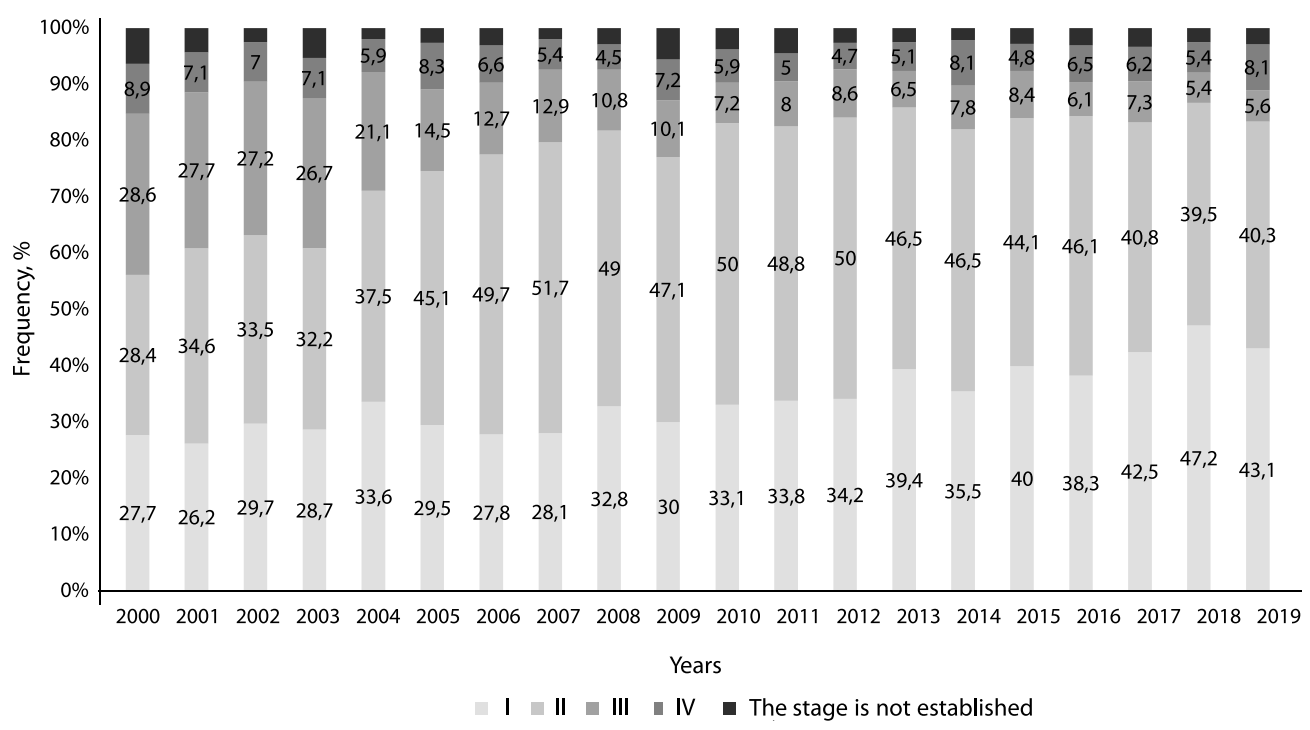

Fig. 4. Melanoma (2009-2019): dynamics of the distribution of newly diagnosed cases by stages [8]

with sunburns received in childhood and adolescence. Melanomas on open areas of the body (head, neck) usually develop as a result of chronic UV exposure to the skin. At the same time, there are some subtypes of melanoma (acral melanoma, mucosal melanoma), the development of which is not associated with UV exposure.

UV radiation causes clear signs of DNA damage and increasing of mutations per megabase, $\mathrm{Mb}$ [6]. The best prevention is physical protection with clothing. One randomized study showed that prevention of UV exposure, including the regular use of sunblock creams, reduced the incidence of primary skin melanoma in the Australian population [7]. Primary prevention continues to play an important role in reducing the incidence of melanoma and non-melanoma skin cancers but is unlikely to change incidence rates in the foreseeable future, considering current trends. Further research will be required to optimize early detection and screening in order to reduce morbidity and mortality from melanoma and non-melanoma skin cancers.

\section{- THE AIM OF THE STUDY}

Was to assess the effectiveness of using the $A B C D+E$ rule in clinical practice for the early diagnosis of pigmented skin lesions.

\section{- MATERIALS AND METHODS}

The study was carried out in 2018-2019 and based at the outpatient surgery department of the N.N. Aleksandrov Oncology Center of Belarus. The study is direct, diagnostic, observational, retrospective, longitudinal, and single-centered. 
Table 1

Study inclusion and exclusion criteria

\begin{tabular}{|l|l|}
\hline Inclusion criteria & Exclusion criteria \\
\hline 1. & $\begin{array}{l}\text { Patients with pigmented skin lesions who applied } \\
\text { for a initial examination by an oncologist for the } \\
\text { purpose of surgical treatment on the basis of }\end{array}$ \\
$\begin{array}{l}\text { outpatient surgery department } \\
\text { Age: } 18 \text { or older }\end{array}$ & None \\
\hline
\end{tabular}

Table 1 shows the inclusion and exclusion criteria which the authors used when developing the study design. The primary selection of candidates was carried out by outpatient oncologists. All patients (854) with pigmented lesions were divided into two groups: 1st - 135 patients with suspicion of melanoma (Suspicio M), 2nd -719 patients with nevi. The volume and nature of the surgical aid were determined by the staff of the oncology department (outpatient surgery department), depending on the clinical diagnosis and following the Belarusian Clinical Protocols "Algorithms for the diagnosis and treatment of malignant neoplasms" [1]. After receiving the results of the postoperative morphological examination, two new groups were formed with final diagnoses: $1 \mathrm{st}-85$ patients with a diagnosis of Melanoma (M), 2nd - 769 patients with other diagnoses, Nevi + Non-Nevi.

The study design is shown in Fig. 5.

Statistical processing of the results was carried out using the Statistica 10.0 software package. The obtained variation series were checked for compliance with the normal distribution by the Shapiro - Wilk method. A pairwise comparison of variation series was carried out using the Mann Whitney test. Evaluation of correlations for the specified parameters in the

CLINICAL EXAMINATION

(patients with pigmented skin lesions)
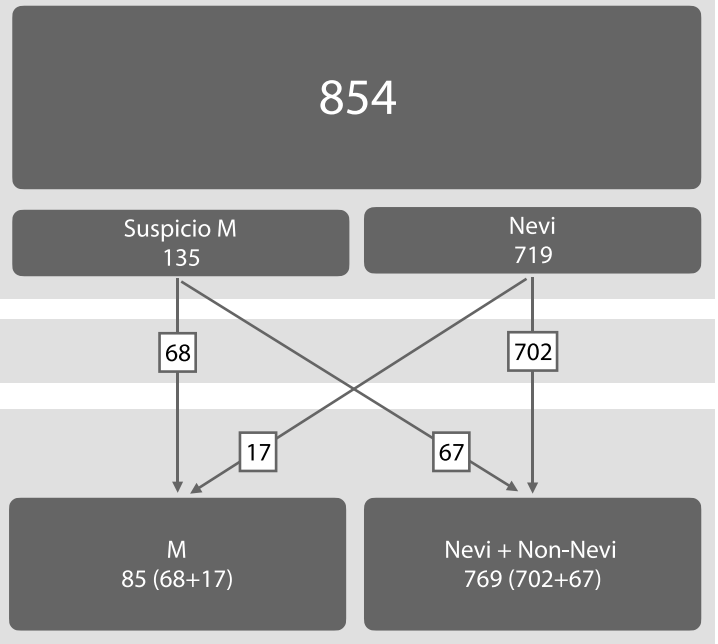

Fig. 5. Study design 
study groups was carried out using the Spearman coefficient. P values less than 0.05 were considered statistically significant. Data are presented by values of the median and the mean \pm error of the mean.

\section{- RESULTS}

Young people (3-4-5 decades of life) were more likely to visit the oncologist for the initial appointment for pigmented lesions (70\%), the average age of those who came for the appointment (854) - 42 years (Fig. 6).

There were no gender differences within group $M$, melanoma was equally common in both men and women (42/43 = M/F). The average age in group $M(85)$ was 48 years, which is statistically significantly higher compared to the general group (Fig. 7). The course of the curves of the distribution frequency (\%) of melanoma in different age categories of the general group (854) and group M (85) mostly imitated each other (orange and gray graphs, Fig. 7). However, when calculating the percentage (\%) of the incidence of melanoma within age groups, there was a clear upward trend of the incidence of melanoma within older age categories, with peaks in the 8th decade of life (yellow graph of Fig. 7).

Lesions localized on the skin sites "head and neck" and "abdominal wall" were equally often observed in both men and women in group $M$ (85) (Table 2). More than half of male melanoma cases were developed on the back and shoulder area (25); there are three sites in the "leaders" for women - the skin of the lower extremities (13), upper extremities (11), back, and shoulder area (11). The localization of pigmented lesions in the Suspicio M group (135) generally repeats the above-described tendency, which gives the authors the right to assert that initial admission doctors have sufficient alertness according to the "characteristic localization of cutaneous melanoma".

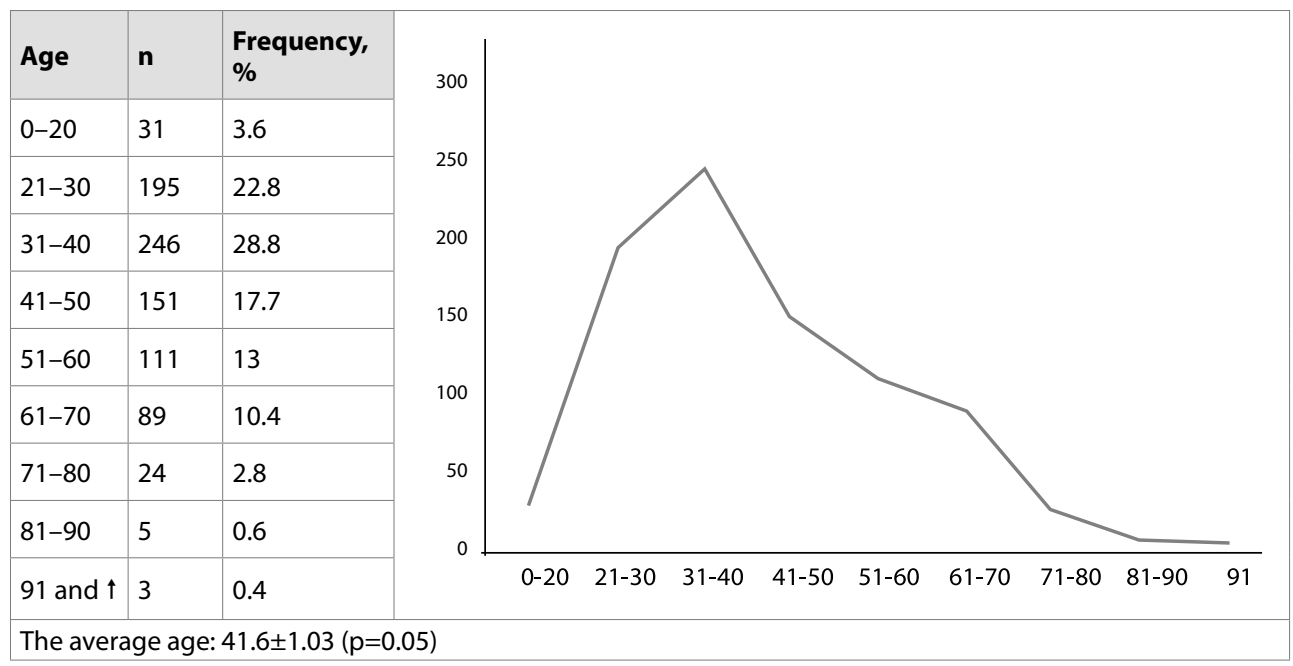

Fig. 6. Distribution of patients by age $(n=854)$ 


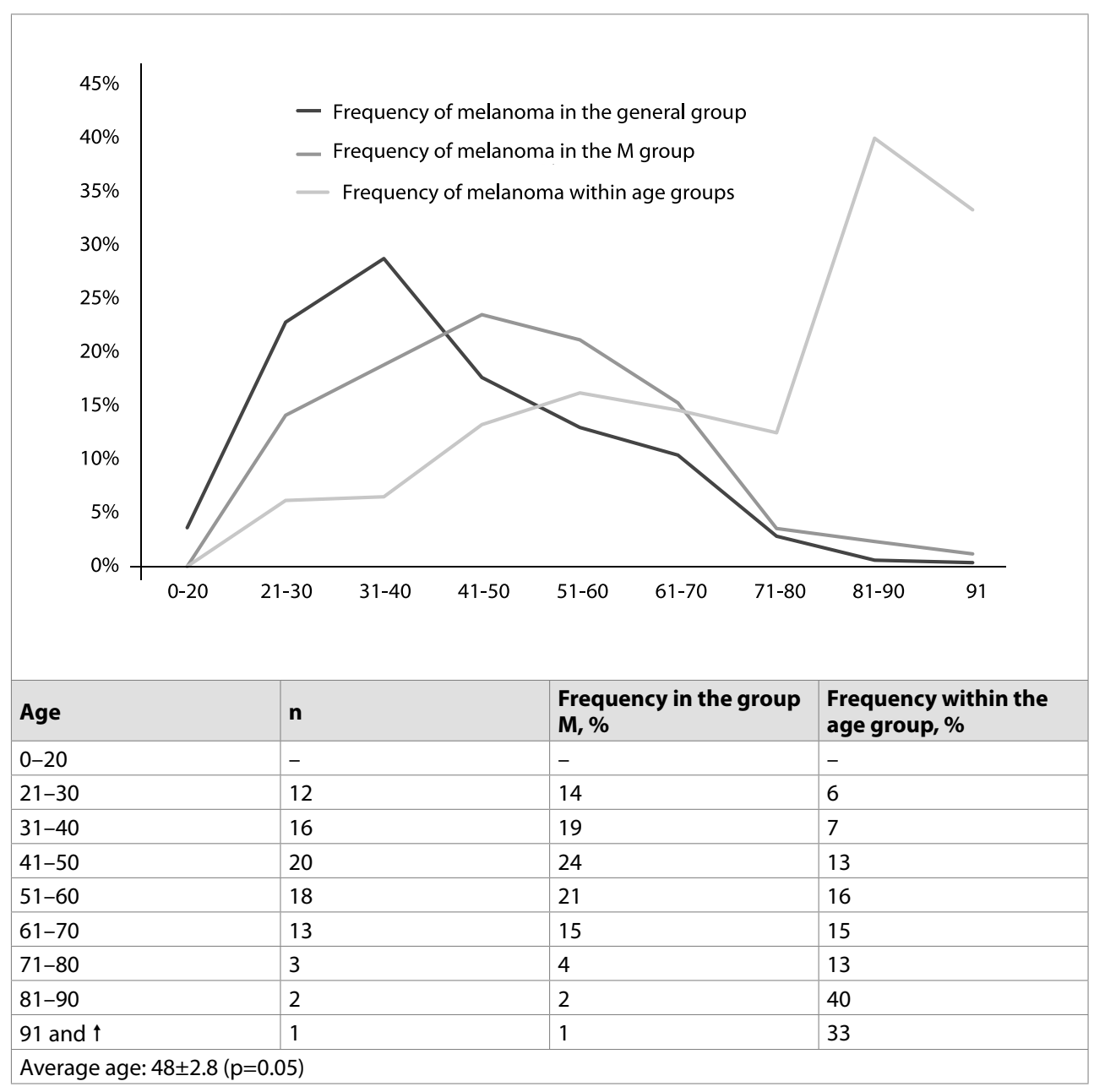

Fig. 7. Group M (85): Distribution of patients by age

The interpretation of the skin pigmented lesions characteristics according to the criteria of the $A B C D+E$ rule by doctors deserves special attention. There was no significant difference in the SC in the following groups: $M(2.08 \pm 0.29)$, Suspicio $M-M(2.31 \pm 0.32)$, Suspicio $M(2.24 \pm 0.22)$, Suspicio $M-$ Non-Melanoma $(2.171 \pm 0.3)$. This means that the visual clinical assessment of the local status at the initial admission is very subjective, and in the comparative example of the M (85) and M - Non-Melanoma (67) groups, it demonstrates its inconsistency in half of the cases (Fig. 8). Furthermore, SC in the cases with pigmented lesions that initially were assessed as nevi and later turned out to be cutaneous melanoma (17) was 2 times significantly lower. 
Table 2

Localization of pigmented lesions

\begin{tabular}{|c|c|c|c|c|c|c|c|c|}
\hline \multirow[t]{2}{*}{ Site } & \multicolumn{2}{|c|}{$\begin{array}{l}\text { Suspicio M } \\
(n=135)\end{array}$} & \multicolumn{2}{|c|}{$\begin{array}{l}\text { Suspicio } M \rightarrow \text { Nevi } \\
+ \text { Non-Nevi } \\
(n=67)\end{array}$} & \multicolumn{2}{|l|}{$\begin{array}{l}M \\
(n=85)\end{array}$} & \multicolumn{2}{|c|}{$\begin{array}{l}\text { Nevi } \rightarrow M \\
(n=17)\end{array}$} \\
\hline & $\begin{array}{l}\text { M (65) } \\
\text { abs./\% }\end{array}$ & $\begin{array}{l}\mathbf{F}(\mathbf{7 0}) \\
\text { abs./\% }\end{array}$ & $\begin{array}{l}M(41) \\
\text { abs./\% }\end{array}$ & $\begin{array}{l}\mathbf{F ( 3 6 )} \\
\text { abs./\% }\end{array}$ & $\begin{array}{l}\text { M (42) } \\
\text { abs./\% }\end{array}$ & $\begin{array}{l}\mathbf{F}(\mathbf{4 3}) \\
\text { abs./\% }\end{array}$ & $\begin{array}{l}M(8) \\
\text { abs./\% }\end{array}$ & $\begin{array}{l}F(9) \\
\text { abs./\% }\end{array}$ \\
\hline Head and neck & $8 / 53$ & $7 / 47$ & $5 / 45$ & $6 / 55$ & $1 / 50$ & $1 / 50$ & - & - \\
\hline Back and shoulders & $31 / 63$ & $18 / 37$ & $13 / 62$ & $8 / 38$ & $25 / 69$ & $11 / 31$ & $5 / 83$ & $1 / 17$ \\
\hline Rib cage $^{1}$ & $4 / 40$ & $6 / 60$ & $3 / 50$ & $3 / 50$ & $2 / 33$ & $4 / 67$ & - & $1 / 100$ \\
\hline Abdominal wall & $6 / 50$ & $6 / 50$ & $4 / 57$ & $3 / 43$ & $3 / 50$ & $3 / 50$ & $1 / 100$ & - \\
\hline Upper extremities & $11 / 48$ & $12 / 52$ & $3 / 50$ & $3 / 50$ & $8 / 42$ & $11 / 58$ & $2 / 50$ & $2 / 50$ \\
\hline Lower extremities $^{2}$ & $5 / 19$ & $21 / 81$ & $13 / 87$ & $13 / 87$ & $3 / 19$ & $13 / 81$ & - & $5 / 100$ \\
\hline
\end{tabular}

Notes: ${ }^{1}$ anterolateral surface; ${ }^{2}$ pelvis and legs.

Assessment of criteria of the clinical rule $A B C D+E$ individually showed the following results (Table 3 ). For group $M(85)$, criterion $A$ (asymmetry) was negative in $92 \%$ of the cases, with the probability of its detection $0.082 \pm 0.0596$ ( 0 - no sign, 1 - there is a sign). Criterion B (border irregularity) and $C$ (heterogeneity of color) were also negative in more than half of the cases - in $60 \%$ and $59 \%$, and the probability of their verification did not exceed 0.4 in both cases (Table 4). Criteria such as diameter (more than 5-7 mm) D and evolution (growth) of element $E$ were positive at $56 \%$ and $62 \%$, respectively. The majority of lesions were less than $5-7 \mathrm{~mm}$ in diameter, as the indicator of detecting a sign was $0.57 \pm 0.11$. The only criterion that demonstrated its "viability" in more than half of the cases was $E(0.62 \pm 0.105)$. However, the $\mathrm{E}$ criterion is not objective during the initial examination, since it is based on the patient's feelings that cannot be checked.
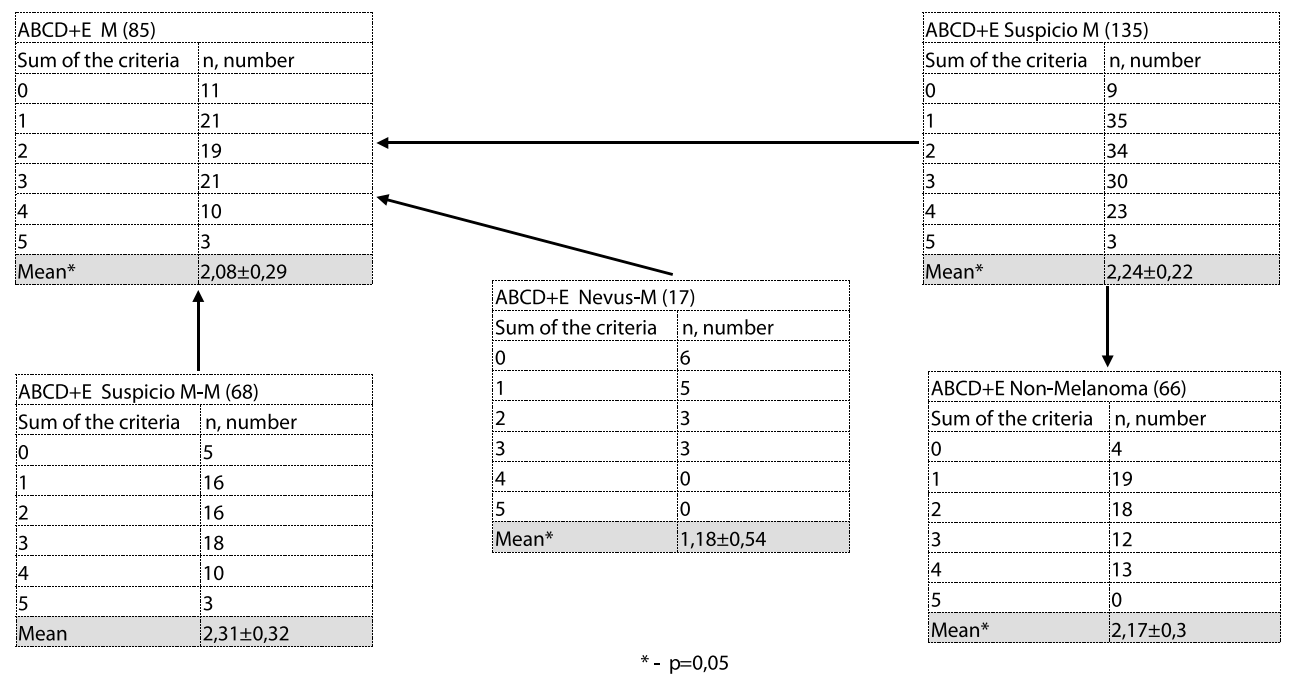

Fig. 8. ABCD+E Rule: Effectiveness Evaluation 
Table 3

Efficiency of the criteria of the rule $A B C D+E$ in groups

\begin{tabular}{|c|c|c|c|c|}
\hline \multicolumn{5}{|l|}{$M(n=85)$} \\
\hline \multirow{2}{*}{ Criterion } & \multicolumn{2}{|c|}{ Criterion } & \multicolumn{2}{|c|}{ Criterion } \\
\hline & $\mathbf{n}$ & $\%$ & $\mathbf{n}$ & $\%$ \\
\hline A & 78 & 92 & 7 & 8 \\
\hline B & 51 & 60 & 34 & 40 \\
\hline $\mathrm{C}$ & 50 & 59 & 35 & 41 \\
\hline $\mathrm{D}$ & 37 & 44 & 48 & 56 \\
\hline $\mathrm{E}$ & 32 & 38 & 53 & 62 \\
\hline \multicolumn{5}{|c|}{ Nevus-M (n=17) } \\
\hline \multirow{2}{*}{ Criterion } & \multicolumn{2}{|c|}{ Criterion- } & \multicolumn{2}{|c|}{ Criterion+ } \\
\hline & $\mathbf{n}$ & $\%$ & $\mathbf{n}$ & $\%$ \\
\hline A & 16 & 94 & 1 & 6 \\
\hline$B$ & 13 & 76 & 4 & 24 \\
\hline $\mathrm{C}$ & 16 & 94 & 1 & 6 \\
\hline $\mathrm{D}$ & 10 & 59 & 7 & 41 \\
\hline$E$ & 10 & 59 & 7 & 41 \\
\hline \multicolumn{5}{|c|}{ Suspicio M (n=135) } \\
\hline \multirow{2}{*}{ Criterion } & \multicolumn{2}{|c|}{ Criterion- } & \multicolumn{2}{|c|}{ Criterion+ } \\
\hline & $\mathbf{n}$ & $\%$ & $\mathbf{n}$ & $\%$ \\
\hline A & 125 & 93 & 10 & 7 \\
\hline B & 82 & 61 & 53 & 39 \\
\hline $\mathrm{C}$ & 64 & 47 & 71 & 53 \\
\hline $\mathrm{D}$ & 57 & 42 & 78 & 58 \\
\hline$E$ & 44 & 33 & 91 & 74 \\
\hline \multicolumn{5}{|c|}{ Suspicio M - Non-M (n=67) } \\
\hline \multirow{2}{*}{ Criterion } & \multicolumn{2}{|c|}{ Criterion- } & \multicolumn{2}{|c|}{ Criterion+ } \\
\hline & $\mathbf{n}$ & $\%$ & $\mathbf{n}$ & $\%$ \\
\hline$A$ & 64 & 95 & 3 & 5 \\
\hline B & 45 & 67 & 22 & 33 \\
\hline C & 30 & 44 & 37 & 56 \\
\hline $\mathrm{D}$ & 30 & 44 & 37 & 56 \\
\hline $\mathrm{E}$ & 22 & 33 & 45 & 67 \\
\hline
\end{tabular}

There is no statistically significant difference in A, B, C, D, and E in patients with suspected melanoma (135), with confirmed melanoma (85), and melanoma, which was described as a nevus at the stage of clinical examination (17) (Table 4). In the Nevi group (67), the C feature (heterogeneity of color of the element) did not work $-0.0625 \pm 0.12$; if we take into account that even in group $M$ it did not rise above $0.41 \pm 0.1$, then it can be stated that its diagnostic value is generally low in any of the studied groups.

The most specific criteria in the clinical assessment of melanoma were criteria A (asymmetry) and B (border irregularity) - 96\% and 67\%, respectively (Table 5). However, their sensitivity can be assessed as low (for A - extremely low, 8\%). Criteria C (color) and D (diameter) had low indicators of both sensitivity and specificity. Sensitivity of criteria E (evolving) was the highest $-62 \%$, but its specificity of $33 \%$ cannot be considered sufficient. 
Table 4

Average values for individual criteria of the rule $A B C D+E^{*}$

\begin{tabular}{|l|l|l|l|l|}
\hline Criterion & Suspicio $\mathbf{M}(\mathbf{n}=\mathbf{1 3 5})$ & $\mathbf{M}(\mathbf{n}=\mathbf{8 5})$ & Nevus-M $(\mathbf{n}=\mathbf{1 7})$ & Nevi $(\mathbf{n}=\mathbf{6 7})$ \\
\hline A & $0.067 \pm 0.043$ & $0.082 \pm 0.0596$ & $0.045 \pm 0.05$ & $0.0625 \pm 0.12$ \\
\hline B & $0.388 \pm 0.084$ & $0.4 \pm 0.1$ & $0.33 \pm 0.12$ & $0.235 \pm 0.22$ \\
\hline C & $0.53 \pm 0.086$ & $0.41 \pm 0.11$ & $0.56 \pm 0.12$ & $0.0625 \pm 0.12$ \\
\hline D & $0.58 \pm 0.085$ & $0.57 \pm 0.11$ & $0.56 \pm 0.12$ & $0.412 \pm 0.25$ \\
\hline E & $0.74 \pm 0.082$ & $0.62 \pm 0.105$ & $0.67 \pm 0.12$ & $0.412 \pm 0.26$ \\
\hline
\end{tabular}

Note: * average value of the sample (where 0 - no feature, 1 - feature) + statistical error.

Table 5

$A B C D+E$ rule: sensitivity/specificity $(n=854)$

\begin{tabular}{|l|l|l|}
\hline A & $\mathbf{8} \%$ & $\mathbf{9 6 \%}$ \\
\hline B & $40 \%$ & $67 \%$ \\
\hline C & $41 \%$ & $44 \%$ \\
\hline D & $57 \%$ & $44 \%$ \\
\hline E & $62 \%$ & $33 \%$ \\
\hline
\end{tabular}

It was difficult for the authors to assess the effectiveness of dermoscopy in the diagnostics of pigmented lesions due to the insufficient number of performed/fixed visualizations. The total number of such examinations is 21 (Table 6). In accordance with the developed 7-point scoring system (Argenziano) of pigmented lesions, doctors indicated the presence of melanoma with an atypical pigment network, a blue-white veil, irregular globules, and uneven pigmentation more often than others [9]. Atypical vascular pattern, regression structures, and irregular streaks were not described in any of the cases.

Table 7 presents the discrepancy between clinical and morphological diagnoses. Non-pigment neoplasms were diagnosed in $20.4 \%$ (147) of patients who were initially diagnosed with nevi: seborrheic keratosis, keratopapilloma, dermatofibroma, basal cell carcinoma, etc. Cutaneous melanoma was diagnosed in 17 patients (2.4\%).

Table 6

Dermoscopic examination results $(n=21)$ in patients with pigmented lesions according to a 7-point system (Argenziano)

\begin{tabular}{|l|l|l|l|l|}
\hline \multirow{2}{*}{ Criteria } & M (12) & \multicolumn{2}{l|}{ Non-M (9) } \\
\cline { 2 - 5 } & Abs. & \% & Abs. & $\%$ \\
\hline Atypical pigment network & 4 & 67 & 2 & 22 \\
\hline Blue-whitish veil & 4 & 67 & 4 & 44 \\
\hline Atypical vascular pattern & - & - & - & - \\
\hline Irregular streaks & - & - & - & - \\
\hline Regression structures & - & - & 1 & 11 \\
\hline Irregular blotches & 2 & 33 & 4 & 44 \\
\hline Irregular dots/globules & 3 & 50 & 2 & 22 \\
\hline
\end{tabular}


In the group of patients with a clinical diagnosis of melanoma, every second patient did not receive its morphological confirmation. "Dysplastic nevus" was identified in $16 \%$ of the cases, basal cell skin cancer was found in another $4 \%$.

The percentage of the discrepancy between clinical and final diagnoses in the clinically formed patient groups "Nevi" and "M" was $23 \%$ and $50 \%$, respectively. The second indicator should influence the revision of approaches in the early diagnosis of cutaneous melanoma. The amount of unreasonably performed radical excisions using anesthetic aids is too high.

The verified morphological types of the identified melanomas (Table 8) were distributed in descending order as follows: superficial spreading (28\%), nodular melanoma (26\%), lentigo maligna (22\%), melanoma in situ (19\%), spindle-cell low pigment melanoma (1\%).

Thin melanomas (in situ and Breslow 1 - up to $0.75 \mathrm{~mm}$ thick) were diagnosed in more than half of the cases (Table 9). The higher the detection

\section{Table 7}

\section{Clinical and final diagnoses: discrepancies}

\begin{tabular}{|c|c|c|c|c|}
\hline \multirow{2}{*}{ Morphological diagnosis } & \multicolumn{2}{|c|}{ Treated as "Nevus" } & \multicolumn{2}{|c|}{ Treated as "Melanoma" } \\
\hline & Abs. & $\%$ & Abs. & 0,7 \\
\hline Actinic keratosis & & & 1 & 3.7 \\
\hline Basal cell carcinoma & 8 & 1.1 & 5 & 5.2 \\
\hline Intradermal nevus & 212 & 29.5 & 7 & 3.7 \\
\hline Hemangioma & 10 & 1.4 & 5 & 1.5 \\
\hline Histiocytoma & - & - & 2 & 3.0 \\
\hline Blue nevus & 17 & 2.4 & 4 & 1.5 \\
\hline Dermatofibroma & 10 & 1.4 & 2 & 15.6 \\
\hline Dysplastic nevus & 70 & 9.7 & 21 & - \\
\hline Keratopapilloma & 24 & 3.3 & - & 1.5 \\
\hline Lentigo & - & - & 2 & - \\
\hline Melanosis & 4 & 0.6 & - & 50.4 \\
\hline Melanoma & 17 & 2.4 & 68 & - \\
\hline Reed's nevus & 3 & 0.4 & - & 1.5 \\
\hline Papilloma & - & - & 2 & - \\
\hline Papillomatous nevus & 41 & 5.7 & - & - \\
\hline Polypus & 1 & 0.1 & - & 5.2 \\
\hline Seborrheic keratosis & 88 & 12.2 & 7 & 2.2 \\
\hline Compound nevus & 84 & 11.7 & 3 & - \\
\hline Mixed nevus & 119 & 16.6 & - & 0.7 \\
\hline Tricholemmoma & 1 & 0.1 & 1 & 1.5 \\
\hline Fibrosis of the skin & - & - & 2 & - \\
\hline Epidermal cyst & 2 & 0.3 & - & 2.2 \\
\hline Junctional nevus & 8 & 1.1 & 3 & 0.7 \\
\hline Total & 719 & 100 & 135 & 100 \\
\hline Discrepancy with clinical diagnosis & $23 \%$ & & $50 \%$ & \\
\hline
\end{tabular}


Table 8

Group M ( $n=85)$ : morphological variants

\begin{tabular}{|l|l|}
\hline Morphological variants & $\mathbf{N} / \%$ \\
\hline In situ & $16 / 19 \%$ \\
\hline Lentigo maligna & $19 / 22 \%$ \\
\hline Nodular melanoma & $22 / 26 \%$ \\
\hline Superficial spreading & $24 / 28 \%$ \\
\hline Spindle-cell low pigment & $1 / 1 \%$ \\
\hline Not indicated & $3 / 4 \%$ \\
\hline
\end{tabular}

\section{Table 9}

Group M ( $\mathbf{n}=85)$ : tumor thickness (mm, Breslow)

\begin{tabular}{|c|c|c|c|}
\hline Thickness M, mm & $\mathbf{n}$ & Breslow & $\mathbf{n}$ \\
\hline in situ & 23 & $\begin{array}{l}1 \text { (dermal component } \\
\text { thickness is less than } \\
0.75 \mathrm{~mm} \text { ) }\end{array}$ & 25 \\
\hline до 1 & 30 & $2(0.75-1.5 \mathrm{~mm})$ & 17 \\
\hline $1.1-1.5$ & 10 & $3(1.51-3.0 \mathrm{~mm})$ & 14 \\
\hline $1.5-3$ & 18 & $4(3.0-4.0 \mathrm{~mm})$ & 3 \\
\hline $3.1-4$ & 2 & 5 (more than $4 \mathrm{~mm}$ ) & 3 \\
\hline More than 4 & 2 & in situ & 23 \\
\hline
\end{tabular}

rate of thin melanomas, the better the survival rates in the near future. The correct and effective organization of early diagnosis of pigmented neoplasms and screening of risk groups for melanoma, in our opinion, will lead to the predicted increase in the incidence of melanoma, mainly due to thin variants and a decrease in mortality rates.

No correlation was found between the thickness of the melanoma and the sum of the $A B C D+E$ rule criteria (Table 10). Even the maximum score of the $A B C D+E$ rule cannot be reliable evidence that the doctor is dealing with melanoma, and vice versa, a low score does not guarantee the absence of a malignant neoplasm.

There are several classifications of malignant melanoma, which allow a differentiated approach to the diagnosis and treatment of the disease. Unfortunately, none of them is recognized as universal, therefore, over time, the systems are revised, updated and/or supplemented. The most significant

\section{Table 10}

$M(n=85)$ : Breslow and $A B C D+E$ rule

\begin{tabular}{|c|c|c|c|c|c|c|c|}
\hline \multirow{2}{*}{ Breslow } & \multicolumn{6}{|c|}{$\Sigma \mathrm{ABCD}+\mathrm{E}$} & \multirow{7}{*}{$\begin{array}{l}r=0.003 \text {. } \\
\text { There is no correlation between the thickness } \\
\text { of melanoma and the sum of the } A B C D+E \text { rule } \\
\text { criteria }\end{array}$} \\
\hline & 0 & 1 & 2 & 3 & 4 & 5 & \\
\hline 1 & 4 & 5 & 4 & 6 & 2 & 2 & \\
\hline 2 & 0 & 6 & 4 & 3 & 2 & 1 & \\
\hline 3 & 2 & 4 & 3 & 3 & 1 & 0 & \\
\hline 4 & 0 & 0 & 1 & 2 & 0 & 0 & \\
\hline 5 & 1 & 0 & 1 & 1 & 0 & 0 & \\
\hline
\end{tabular}


Table 11

Classification of melanoma, category $\mathrm{T}$ (primary tumor) according to the AJCC version $\left(8^{\text {th }}\right.$ and $7^{\text {th }}$ revisions), adapted from [12]

\begin{tabular}{|c|c|c|c|c|}
\hline \multirow{2}{*}{$\mathrm{T}$} & \multicolumn{2}{|c|}{$8^{\text {th }}$ revision AJCC (2018) } & \multicolumn{2}{|c|}{$7^{\text {th }}$ revision AJCC (2010) } \\
\hline & Thickness & Ulceration & Thickness & Ulceration \\
\hline TX & Not applicable & Not applicable & Not applicable & Not applicable \\
\hline T0 & Not applicable & Not applicable & Not applicable & Not applicable \\
\hline Tis & Not applicable & Not applicable & Not applicable & Not applicable \\
\hline $\begin{array}{l}\text { T1 } \\
\text { T1a } \\
\text { T1b }\end{array}$ & $\begin{array}{l}\leq 1.0 \mathrm{~mm} \\
<0.8 \mathrm{~mm} \\
<0.8 \mathrm{~mm} \\
0.8-1.0 \mathrm{~mm}\end{array}$ & $\begin{array}{l}\text { Unknown or not } \\
\text { specified } \\
\text { Without ulceration } \\
\text { With ulceration } \\
\text { With/without } \\
\text { ulceration }\end{array}$ & $\begin{array}{l}\leq 1.0 \mathrm{~mm} \\
\leq 1.0 \mathrm{~mm} \\
\leq 1.0 \mathrm{~mm}\end{array}$ & $\begin{array}{l}\text { Unknown or not } \\
\text { specified } \\
\text { Without ulceration } \\
\text { and }<1 \text { mitosis } / \mathrm{mm}^{2} \\
\text { With ulceration } \\
\text { and } \geq 1 \text { mitosis } / \mathrm{mm}^{2}\end{array}$ \\
\hline $\begin{array}{l}\text { T2 } \\
\text { T2a } \\
\text { T2b }\end{array}$ & $\begin{array}{l}>1.0-2.0 \mathrm{~mm} \\
>1.0-2.0 \mathrm{~mm} \\
>1.0-2.0 \mathrm{~mm}\end{array}$ & $\begin{array}{l}\text { Unknown or not } \\
\text { specified } \\
\text { Without ulceration } \\
\text { With ulceration }\end{array}$ & $\begin{array}{l}1.01-2.0 \mathrm{~mm} \\
1.01-2.0 \mathrm{~mm} \\
1.01-2.0 \mathrm{~mm}\end{array}$ & $\begin{array}{l}\text { Unknown or not } \\
\text { specified } \\
\text { Without ulceration } \\
\text { With ulceration }\end{array}$ \\
\hline $\begin{array}{l}\text { T3 } \\
\text { T3a } \\
\text { T3b }\end{array}$ & $\begin{array}{l}>2.0-4.0 \mathrm{~mm} \\
>2.0-4.0 \mathrm{~mm} \\
>2.0-4.0 \mathrm{~mm}\end{array}$ & $\begin{array}{l}\text { Unknown or not } \\
\text { specified } \\
\text { Without ulceration } \\
\text { With ulceration }\end{array}$ & $\begin{array}{l}2.01-4.0 \mathrm{~mm} \\
2.01-4.0 \mathrm{~mm} \\
2.01-4.0 \mathrm{~mm}\end{array}$ & $\begin{array}{l}\text { Unknown or not } \\
\text { specified } \\
\text { Without ulceration } \\
\text { With ulceration }\end{array}$ \\
\hline $\begin{array}{l}\text { T4 } \\
\text { T4a } \\
\text { T4b }\end{array}$ & $\begin{array}{l}>4.0 \mathrm{~mm} \\
>4.0 \mathrm{~mm} \\
>4.0 \mathrm{~mm}\end{array}$ & $\begin{array}{l}\text { Unknown or not } \\
\text { specified } \\
\text { Without ulceration } \\
\text { With ulceration }\end{array}$ & $\begin{array}{l}>4.0 \mathrm{~mm} \\
>4.0 \mathrm{~mm} \\
>4.0 \mathrm{~mm}\end{array}$ & $\begin{array}{l}\text { Unknown or not } \\
\text { specified } \\
\text { Without ulceration } \\
\text { With ulceration }\end{array}$ \\
\hline
\end{tabular}

Notes: TX - the thickness of the primary tumor cannot be determined (for example, when diagnosed as a result of curettage); TO - absence of signs of a primary tumor (for example, unknown primary or completely regressed melanoma); Tis - melanoma in situ.

changes were made to the classification of melanoma staging in 2010. Recommended by the AJCC (American Joint Committee on Cancer), they began to include an accurate diagnosis and prognosis of the development of the disease [10]. In 2018 this classification was also revised (Table 11) [11].

For the analysis of the international melanoma database used in the 8th revision AJCC classification, patients with primary melanoma without signs of a regional or distant metastatic process were divided into 8 subcategories according to the $\mathrm{T}$ criterion (T1a-T4b). Patients with $\mathrm{T} 1$ melanoma were included in the data analysis if clinical or pathological findings were corresponding to T1N0. Patients with T2-T4 melanoma were included only if they had undergone lymphatic mapping and sentinel lymph node (SLN) biopsy and had no tumor-bearing SLN or satellites or in-transit metastases at the time of diagnosis or after completion of initial treatment ( $\mathrm{pNO}$ melanoma).

Primary tumor thickness (Breslow) and ulceration are major predictors of survival and T grade stratification in cutaneous melanoma [13-15]. The $8^{\text {th }}$ revision of AJCC recommends measuring the thickness of the tumor with an accuracy of $0.1 \mathrm{~mm}$, and not with an accuracy of $0.01 \mathrm{~mm}$ (as in previous versions). At the same time, category T, as before, is defined by the threshold values for melanoma thickness of 1.0, 2.0 and $4.0 \mathrm{~mm}$. Thus, tumors ranging 
in size from 0.95 to $1.04 \mathrm{~mm}$ should be rounded to $1.0 \mathrm{~mm}$ (i.e., $\mathrm{T} 1 \mathrm{~b}$ ); previously (AJCC 7th revision) melanomas of 1.01-1.04 were defined as T2 (a - without ulceration; b - with ulceration) $[10,11]$. The clinical outlook (if any) of this small subset of patients in a lower stage, according to the $8^{\text {th }}$ revision of the classification, has not yet been formally studied [16].

In previous versions of the classification, the clinically significant threshold in patients with T1 melanoma was defined by $0.7-0.8 \mathrm{~mm}$ [1416]. In the eighth edition of the AJCC, a multivariate analysis was used to analyze a cohort of patients with $\mathrm{T} 1$ melanoma to predict melanomaspecific survival (MSS); i.e., tumor thickness, ulceration, number of mitoses, as a dichotomous variable ( $<1$ mitosis $/ \mathrm{mm}^{2}$ versus $\left.\geq 1 \mathrm{mitosis} / \mathrm{mm}^{2}\right)$ showed that the dichotomy of tumor thickness as $<0.8 \mathrm{~mm}$ and $0.8-1.0 \mathrm{~mm}$ and ulceration were better predictors of MSS than the mitotic rate (as a dichotomous variable) $[11,17]$. The definitions of T1a and T1b have been revised so that T1a melanoma includes those $<0.8 \mathrm{~mm}$ without ulceration, while T1 b melanoma includes those $0.8-1 \mathrm{~mm}$ with or without ulceration and those $<0.8 \mathrm{~mm}$ with ulceration.

Even though the number of mitoses (mitosis per $1 \mathrm{~mm}^{2}$ ) remains the main prognostic factor for melanomas of all thickness categories, this feature is no longer used as a criterion for category $T$ in the eighth version of the classification. However, it is strongly recommended to document this feature for all patients [11].

Table 12 provides information on category T of final diagnoses in group $M$.

The issue of unification of the primary dermato-oncological approach should be revised. The $A B C D+E$ rule should be considered as an initial descriptive stage. The following categories should also be added to the examination checklist: genotype, personal and family history of skin lesions, the number of nevi and their nature (dysplastic nevi), phenotypic signs (hair color, freckles, eye color, tanning regime). The relative risks for each of the above criteria are described by Psaty E.L. et al. in 2010 (table 13) [1].

Dermoscopy should be considered as the final and obligatory link in the non-invasive pigment assessment. Several studies show that the widespread introduction of imaging techniques into dermato-oncological practice not only improves the quality of melanoma diagnostics but also makes it possible to reduce the number of unnecessary surgical interventions by $30 \%[18-20]$.

\section{Table 12}

Group M (85): distribution of final diagnoses by category $T$

\begin{tabular}{|l|l|l|}
\hline pT & n & ulceration \\
\hline pTis & 21 & - \\
\hline pT1a & 34 & - \\
\hline pT1b & 2 & 0 \\
\hline pT2a & 17 & - \\
\hline pT2b & 3 & 3 \\
\hline pT3a & 2 & - \\
\hline pT3b & 3 & 3 \\
\hline pT4a & 1 & - \\
\hline pT4b & 2 & 2 \\
\hline
\end{tabular}

Note: pTis - melanoma in situ. 


\section{Table 13}

Melanoma: Estimated Risk Factors, adapted from [1]

\begin{tabular}{|c|c|c|}
\hline Categories & Signs & $\begin{array}{l}\text { Risk } \\
\text { (as relative risk with } 95 \% \text { confidence } \\
\text { interval, unless otherwise noted) }\end{array}$ \\
\hline Genotype & $\begin{array}{l}\text { Xeroderma pigmentosum } \\
\text { CDKN2A } \\
\text { Suspicious: } \\
\text { In families with multiple melanomas or } \\
\text { pancreatic cancer } \\
\text { CDK4 (very rare) } \\
\text { BRCA2 - families with breast and ovarian } \\
\text { cancer } \\
\text { MC1R } \\
\text { Suspicious: } \\
\text { Caucasians with red hair, freckles } \\
\text { OCA2 } \\
\text { Suspicious: } \\
\text { Patients with family history of albinism }\end{array}$ & $\begin{array}{l}\text { About one in five people develop } \\
\text { melanoma } \\
35-70 \text { times } \\
67 \% \text { lifetime risk } \\
\text { Significantly increased } \\
2.58 \text { ( } 1.28-5.17) \\
2-3.5 \\
\text { Low risk, regardless of phenotype }\end{array}$ \\
\hline $\begin{array}{l}\text { Personal history of } \\
\text { cutaneous lesions }\end{array}$ & $\begin{array}{l}\text { Melanoma } \\
\text { Non-melanoma skin cancers (including } \\
\text { actinic lesions) }\end{array}$ & $\begin{array}{l}1-8 \% \text { of melanoma patients will be re- } \\
\text { diagnosed with melanoma } \\
4.28(2.8-6.55)\end{array}$ \\
\hline Family history & $\begin{array}{l}\text { Relatives } \\
\text { Parent }\end{array}$ & $\begin{array}{l}1.74(1.41-2.14) \\
2.4(2.1-2.72) \\
3.2(2.6-3.9) \text { for men of North America } \\
4.4(3.5-5.2) \text { for women of North America } \\
2.98(2.54-3.47) \\
3.2(2.6-3.9) \text { for men of North America } \\
4.4(3.5-5.2) \text { for women of North America }\end{array}$ \\
\hline & $\begin{array}{l}\text { Two first-line relatives } \\
\text { Parent with multiple primary melanomas }\end{array}$ & $\begin{array}{l}8.92(4.25-15.31) \\
61.78(5.82-227.19)\end{array}$ \\
\hline Atypical nevi & $\begin{array}{l}0 \\
1 \\
2 \\
3 \\
4 \\
5\end{array}$ & $\begin{array}{l}1.0 \\
1.45(1.31-1.6) \\
2.1(1.71-2.54) \\
3.03(2.23-4.06) \\
4.39(2.91-6.47) \\
6.36(3.8-10.33)\end{array}$ \\
\hline Nevi & $\begin{array}{l}0-15 \\
16-40 \\
41-60 \\
61-80 \\
81-100 \\
101-120\end{array}$ & $\begin{array}{l}1.0 \\
1.47(1.36-1.59) \\
2.24(1.9-2.64) \\
3.26(2.55-4.15) \\
4.74(3.44-6.53) \\
6.89(4.63-10.25)\end{array}$ \\
\hline \multicolumn{3}{|l|}{ Phenotypic traits } \\
\hline Hair color & $\begin{array}{l}\text { Red vs dark } \\
\text { Blonde vs dark } \\
\text { Light blond vs dark }\end{array}$ & $\begin{array}{l}3.64(2.56-5.37) \\
1.96(1.41-2.74) \\
1.62(1.11-2.34)\end{array}$ \\
\hline
\end{tabular}




Table 13 end
\begin{tabular}{|l|l|l|}
\hline Freckles & Large vs small amount & $2.1(1.8-2.45)$ \\
\hline Eye color & Light (green, light brown, blue) vs brown & $\sim 1.5$ \\
\hline & Intermittent & $2.35(1.78-3.09)$ \\
Taning (mode) & Chronic & $0.98(0.85-1.12)$ \\
& History of sunburns & $2.02(1.73-2.34)$ \\
& Solarium & Ever vs never. 1.15 (1.0-1.31) \\
\hline
\end{tabular}

Why does dermoscopy help to better diagnose cutaneous melanoma? First, the method is capable of detecting pathognomonic micro visual signs that become apparent much earlier than clinical changes. Second, a physician skilled in the dermoscopic assessment of pigmented lesions is more concerned with checking for trite-looking lesions, considering it a «level 1» screening tool. Thirdly, the doctors get the opportunity of detailed observation of the lesion using high-precision digital dermoscopy [21]. The unification of the initial clinical examination should be followed by the unification of the dermoscopic assessment of the pigment. An adequate and convenient scale/system of the algorithm for detecting pigmented lesions should be based on several comparative studies to assess their sensitivity and effectiveness. Carrying out morpho-dermoscopic correlations will facilitate the search for new visual non-invasive characteristics/signs of pigmented lesions.

\section{- CONCLUSION}

The $A B C D+E$ rule nowadays does not have sufficient sensitivity and specificity and can be considered only as a descriptive characteristic of the local status of pigmented lesions. The initial dermato-oncological examination should be carried out taking into account the assessment of the individual relative risks for developing skin melanoma. The checklist must contain information about genotype, personal and family history of skin neoplasms, the number, and quality of recorded nevi (dysplastic nevi), phenotypic traits (hair color, freckles, eye color, tanning regime). Dermoscopy should be considered as a mandatory option for non-invasive pigmented lesions assessment, capable of providing early verification of melanoma at the preclinical stage.

The unification of the algorithm for non-invasive diagnostics will contribute to the development of an authentic screening program for melanoma and non-melanoma skin cancers in Belarus.

Conflict of interest. The authors declare no conflict of interest.

\section{- REFERENCES}

1. Psaty EL, Scope A, Halpern AC, Marghoob AA. Defining the patient at high risk for melanoma. Int J Dermatol. 2010;49: 362-367.

2. Belarusian National Guidelines: Diagnostic procedures and treatment of malignant neoplasms. Professional Publications, Minsk. $2019.616 \mathrm{p}$.

3. Hollestein LM, van den Akker SAW, Nijsten T et al. Trends of cutane - ous melanoma in The Netherlands: increasing incidence rates among all Breslow thickness categories and rising mortality rates since 1989. Ann Oncol 2012; 23(2): 524-530.

4. Available at: https://www.cancerresearchuk.org. Access date: 28.07.2021. Cancer Research UK Melanoma skin cancer incidence statistics. 
5. Forsea AM, Del Marmol V, Stratigos A, Geller AC. Melanoma prognosis in Europe: far from equal. Br J Dermatol 2014; 171(1): 179-182.

6. Alexandrov LB, Nik-Zainal S, Wedge DC et al. Signatures of mutational processes in human cancer. Nature 2013; 500(7463): 415.

7. Green AC, Williams GM, Logan V, Strutton GM. Reduced melanoma after regular sunscreen use: randomized trial follow-up. J Clin Oncol 2011; 29(3): 257-263.

8. Database of the Belarusian Cancer Register, 2021.

9. Argenziano G, Catricala C, Ardigo M, Buccini P, De Simone P, Eibenschutz L, Ferrari A, Mariani G, Silipo V, Sperduti I, Zalaudek I. Seven-point checklist of dermoscopy revisited. Br J Dermatol. 2011; 164(4): 785-90.

10. Balch CM, Soong SJ, Gershenwald JE, et al. Melanoma of the skin Edge S, Byrd D, Compton C, et al. eds. AJCC Cancer Staging Manual. 7th ed. New York: Springer Verlag; 2009: 325-344.

11. Gershenwald JE, Scolyer RA, Hess KR, et al.Melanoma of the Skin Amin M, Edge SB, Greene FL, et al. eds. AJCC Cancer Staging Manual. 8th ed. Switzerland: Springer; 2017: 563-585.

12. Keung EZ, Gershenwald JE. The eighth edition American Joint Committee on Cancer (AJCC) melanoma staging system: implications for melanoma treatment and care. Expert Rev Anticancer Ther. 2018; 18(8): 775-784.

13. Breslow A Tumor thickness, level of invasion and node dissection in stage I cutaneous melanoma. Ann Surg. 1975; 182(5): 572-575.

14. Green AC, Baade P, Coory M, et al. 20-year survival among people diagnosed with thin melanomas in Queensland, Australia. J Clin Oncol. 2012; 30(13): 1462-1467.

15. Hout FE, Haydu LE, Murali R, Bonenkamp JJ, et al. Prognostic importance of the extent of ulceration in patients with clinically localized cutaneous melanoma. Ann Surg. 2012; 255(6): 1165-1170.

16. Gimotty PA, Elder DE, Fraker DL, et al. Identification of high-risk patients among those diagnosed with thin cutaneous melanomas. J Clin Oncol. 2007; 25(9): 1129-1134.

17. Gershenwald JE, Scolyer RA, Hess KR, et al. Melanoma staging: evidence-based changes in the American Joint Committee on Cancer eighth edition cancer staging manual. CA Cancer J Clin. 2017; 67(6): 472-492.

18. Vestergaard ME, Macaskill P, Holt PE, Menzies SW. Dermoscopy compared with naked eye examination for the diagnosis of primary melanoma: a meta-analysis of studies performed in a clinical setting. Br J Dermatol. 2008; 159: 669-676.

19. Mayer J. Systematic review of the diagnostic accuracy of dermatoscopy in detecting malignant melanoma. Med J Aust. 1997; 167: 206-210.

20. Carli P, De Giorgi V, Crocetti E et al. Improvement of malignant/benign ratio in excised melanocytic lesions in the'dermoscopy era': a retrospective study 1997-2001. Br J Dermatol. 2004; 150: 687-692.

21. Argenziano G, Ferrara G, Francione S, Di Nicola K, Martino A, Zalaudek I. Dermoscopy - the ultimate tool for melanoma diagnosis. Semin Cutan Med Surg. 2009; 28: 142-148.

22. Available at: https://dermcoll.edu.au/wp-content. Access: 16.09.2021. Cancer Council Australia. Position statement - Screening and early detection of skin cancer.

23. Available at: https://nhmrc.gov.au/_files_nhmrc. Access: 16.09.2021. Cancer Council Australia and Australian Cancer Network and New Zealand Guidelines Group. Clinical practice guidelines for the management of melanoma in Australia and New Zealand: evidence-based best practice guidelines.

24. Available at: http://racgp.org.au/your-practice/guidelines. Access: 16.09.2021. Royal Australian College of General Practitioners. Guidelines for preventive activities in general practice.

25. Marsden JR, Newton-Bishop JA, Burrows L et al. Revised UK Guidelines for the management of cutaneous melanoma. J Plast Reconstr Aesthet Surg. 2010; 63(9): 1401-1419.

26. Available at: http://oncoline.nl/uploaded/docs. Access: 16.09.2021. Dutch Working Group of Melanoma Guideline 2012 (2013).

27. Katalinic A, Eisemann N, Waldmann A. Skin cancer screening in Germany. Documenting melanoma incidence and mortality from 2008 to 2013. Dtsch Artztebl Int. 2015; 112(38): 629-634.

28. Available at: http://leitlinienprogramm-onkologie.de. Access: 16.09.2021. German Guideline Program in Oncology (GGPO). Evidence-based guideline on prevention of skin cancer (short version).

29. Available at: https://aad.org/education/basic-derm. Access: 16.09.2021. American Academy of Dermatology. Learning module: the skin exam.

30. O'Neill CH, Scoggins CR. Melanoma. J Surg Oncol. 2019. DOI: 10.1002/jso.25604

31. Friedman RJ, Rigel DS, Kopf AW. Early detection of malignant melanoma: the role of physician examination and self-examination of the skin. CA Cancer J Clin. 1985; 35:130-151.

32. Abbasi NR, Shaw HM, Rigel DS, et al. Early diagnosis of cutaneous melanoma: revisiting the ABCD criteria. JAMA. 2004; 292: 2771-2776.

Submitted/Подана: 20.09.2021

Accepted/Принята: 24.09.2021

Contacts/Контакты: alexlukyanau@gmail.com 